\title{
Un 'telaio' teorico e le sue linee. II Filo dell'Alleanza
}

\author{
Gaetano Ginex
}

Abstract

Si mette in mostra in questo scritto, un anelito di ricongiungimento di luoghi e di anime lontane, un'apertura agli intrecci culturali in una ricerca d'armonia tra le genti nel segno della bellezza e dell'humanitas. Si parla di un'opera collettiva che coinvolge un gruppo di donne tra Israele e Palestina, in un progetto che promuove integrazione e convivenza nel Mediterraneo e nel Medio Oriente attraverso l'arte del ricamo che diventa strumento per rappresentare relazioni, contatti umani, scambi di vite, parole e culture che si intrecciano. Si allude ad un racconto delle origini del mondo riconoscendo a culture differenti una piena legittimità e dignità come culture che hanno impostato diversamente da noi le proprie linee di sviluppo e di esistenza. Un tentativo di rileggere criticamente le vicende della nostra civiltà attraverso un 'telaio' e un 'ricamo' che ha per tema la connessione che intercorre nelle complesse relazioni tra i popoli del Mediterraneo, in cui il disegno può essere un connettivo ultimo e luogo in cui tutte le comunità si identificano in un atto semplice e al contempo duraturo, attraverso la metafora del ricamo in un messaggio che passa per il 'sangue' dei popoli che unisce vite differenti in perenne conflitto. Si racconta di una storia di solidarietà in cui la terra e il mare sono legati da un filo d'oro che si fonde con la mappatura genetica del sangue di tutte le donne e gli uomini del Mediterraneo. Connettere testo, parola e pensiero che interagiscono attraverso un gesto artistico.

Parole chiave

Mediterraneo, gene, ricamo, filo, tessere, classificazione.

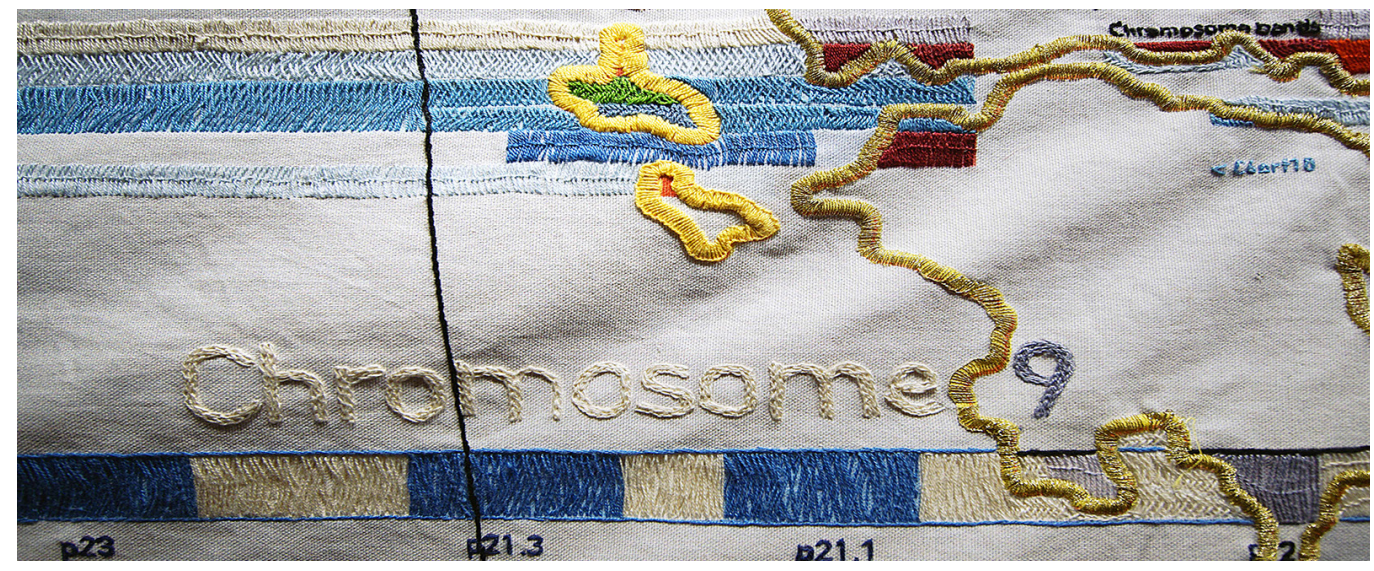


"Come il movimento di cui costituisce la misura, il tempo non può che compiersi in uno spazio. Se il primo è il luogo e il simbolo dell'imperfezione lo sarà anche il secondo; se il primo è un insieme di istanti discontinui, il secondo non sarà che un insieme di punti.

Esattamente come il tempo, lo spazio è l'intermediario che assegna all'uomo la precarietà di una vita terrena c he egli attraversa come un fragile ponte per innalzarsi al cielo dove ha luogo l'esistenza divina e assoluta. Questo modo di ridurre il tempo a un istante e lo spazio ad un punto annulla la stessa nozione di casualità"

[Adonis 2002]

Il luogo fisico in cui si stabilisce comunemente un rapporto tra le comunità umane e il territorio geografico, tra l'individuo e la totalità del mondo, è la casa, che costituisce infatti la matrice di tutti gli interventi architettonici che i gruppi umani hanno prodotto e producono nel tempo: dalla tomba al focolare, al riparo, all'alloggio, alla piazza, al tempio, alla città, al territorio intero. La casa è infatti un 'principio archetipico', estremamente complesso è il luogo primordiale dell'abitare e il campo topologico fondamentale dell'architettura [Ugo 1976, pp. 53-6I] [I]. Si può anche avere una esigenza teorica e artistica di una metaforizzazione del fare architettonico applicare cioè una tecnica diversa dall'atto fisico, materico e semantico del costruire una casa e costruire una 'metafora architetturale' al fine di connettere senza peccare di arbitrarietà due campi non omogenei come quello dello spazio fisico, della costruzione materiale e quello artistico in cui gesto, testo, parola e pensiero interagiscono attraverso un prodotto artistico. "Le definizioni di forma da un lato e di simbolo dall'altro infatti sono idee molto concrete ovvero si tratta cioè di compierne, come dice Foucault, un'archeologia, un'analisi che non può essere disgiunta dall'uso e dalla sua attualità" [Foucault I97 I, pp. I55- I 58] [2] Si allude a questo punto al concetto e spiegazione delle origini del mondo, di classificazione e ordinamento primitivo di cose e fenomeni. In altre parole riconoscendo ad altre culture piena legittimità e dignità, dando ad esse una possibilità nuova di rileggere criticamente le vicende della nostra civiltà senza troppe facili certezze. Sia un testo scritto, sia un procedimento progettuale che un atto artistico porta in sé un'intenzione ordinatrice, affinché le parti separate da eventi della vita possano sempre riaggregarsi in unità e comunicare messaggi universali carichi di principi archetipici. Sono questi i termini che costituiscono il 'telaio' all'interno del quale abbiamo cercato una corretta collocazione di queste note in armonia alle connessioni complesse che intercorrono negli innumerevoli campi del sapere ma anche tra più cose in cui il disegno può essere un connettivo ultimo per la conoscenza di campi culturali legati alle parole, al racconto e al mito. Quindi da un lato il mito della casa come luogo in cui tutte le comunità si identificano in un atto semplice universale e duraturo come l'abitare e dall'altro la metaforizzazione di questo atto abitativo come simbolo di una più profonda identificazione delle comunità tutte che sceglie il 'san-

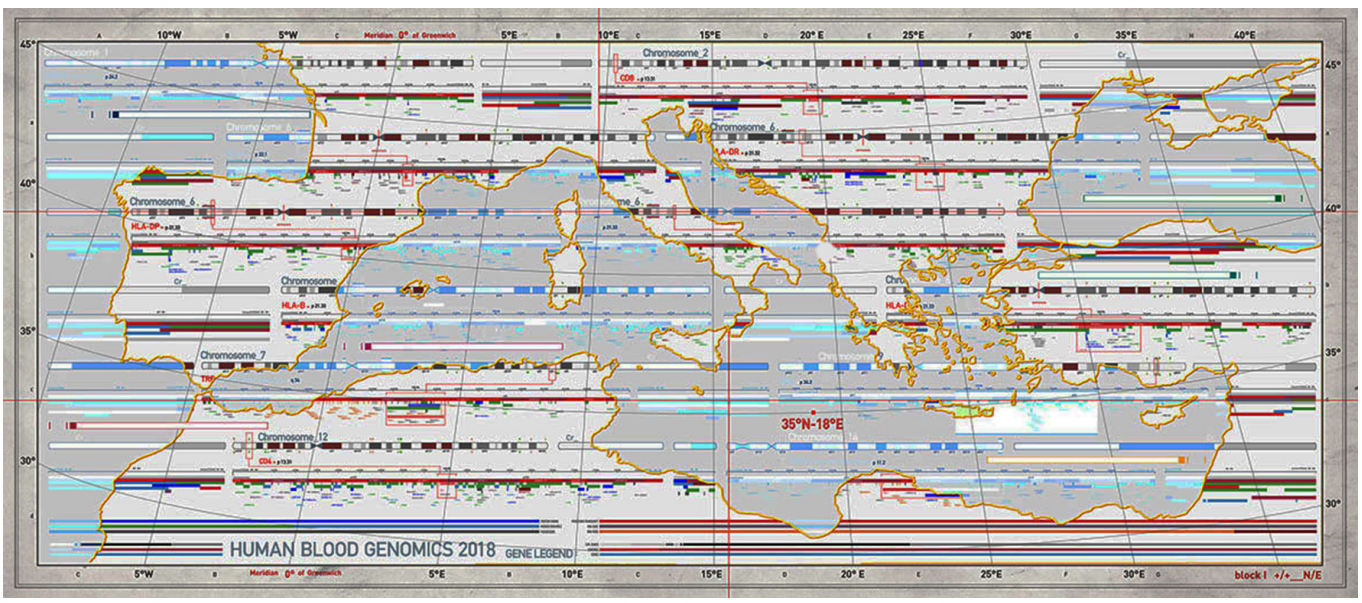


gue' come veicolo di universale fratellanza [3]. II Mediterraneo, un mistero culturale, eterno luogo di dialogo e di connessioni ma contemporaneamente luogo di conflitti e divisioni che induce ad una riflessione che incarna un infinito dialogo tra civiltà e culture, tracciando una lunga catena di significati per giungere ad una visione che in modo trasversale toccherà $i$ temi del dialogo della fratellanza della comunità tra i popoli assumendo come per incanto le sembianze di un filo d'oro, di un nastro, di una corda che in una ipotetica struttura formale si snoda tra i suoi confini. Narrare uno spazio in cui un semplice filo mette in evidenza un sapere universale che con sottile eleganza annoda e tesse una serialità tassonomica che evoca luoghi, conflitti e guerre da sempre. Un'unica tela divisa in sei parti che compone una unità inscindibile. Un'idea che offre l'occasione di 'connettere' e confrontare un'intenzione e una forma al di fuori della realtà sensibile. Una rappresentazione di elementi privi di con-

Fig. 2. L'arazzo che rappresenta il Mar Mediterraneo.

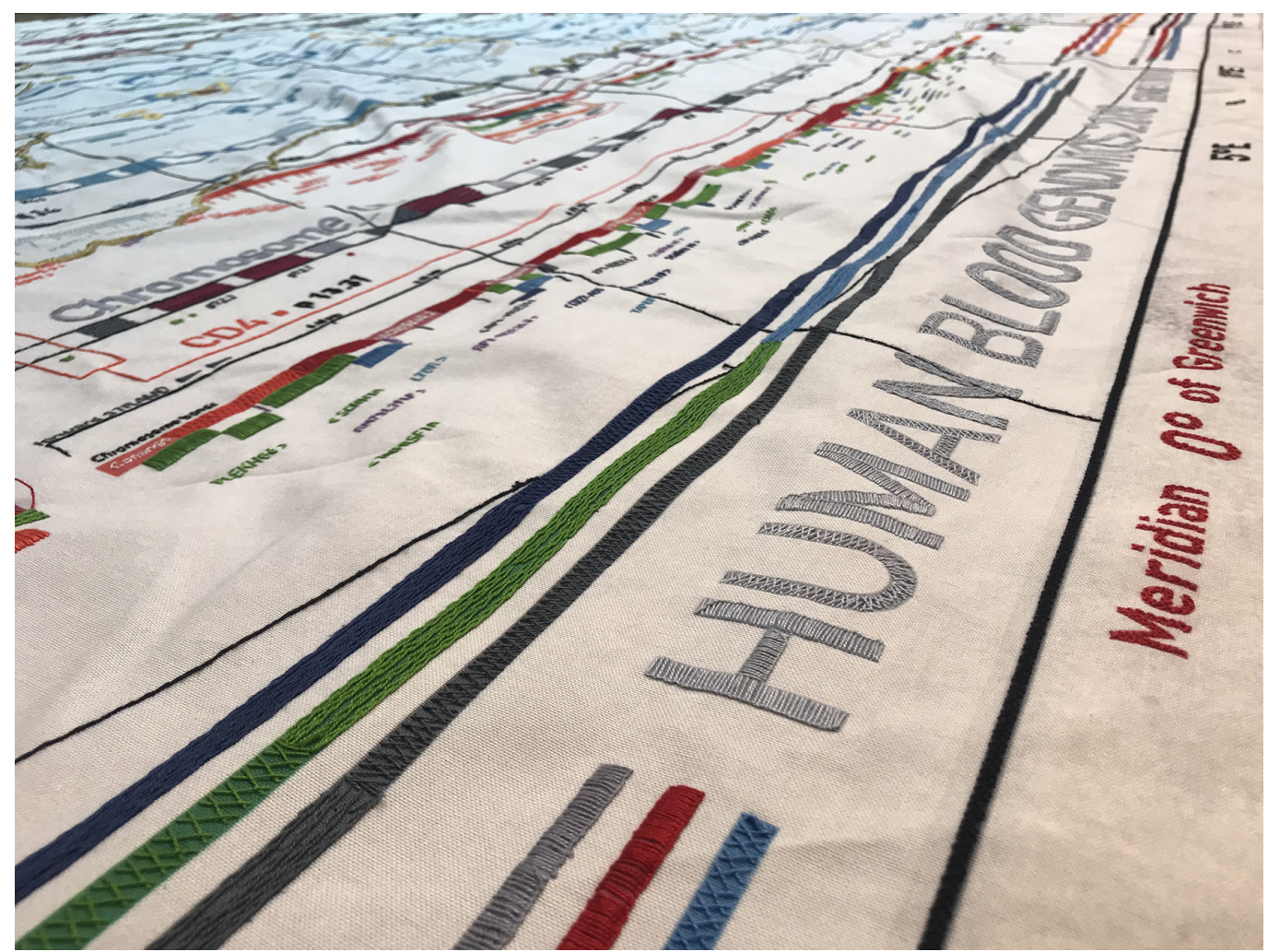

gruenza spaziale in una raffigurazione dei codici genetici e, più in generale, di tutte le idee e le forme che non possono essere descritte entro i limiti e le regole dello spazio cartesiano. Spazio, tempo, luogo e storia si mettono simultaneamente in opera in un tentativo di fissare i principali contesti nei quali ordire e tessere un messaggio attraverso un lavoro di ricamo associato al genoma umano, il sangue dell'uomo ricavandone un disegno del Mare Nostrum [4] nel tentativo di fissare i principali contesti nei quali il messaggio può essere paradigmaticamente condensato. Il contesto del 'rito' e del 'mito' come campo della memoria perenne, il contesto dell 'utopia' che cristallizza lo spazio come memoria assente e in ultimo il contesto dell'eterotopia (fuori tempo e fuori luogo) come momento poetico e campo della memoria critica [5]. In questa ottica si ottiene un sistema complesso in un ordito che comprende tre piani concettuali: lo spazio contenitore, il Mediterraneo, lo spazio analogico del disegno rappresentato dalla tela e il campo genetico di riferimento rappresentato dalla mappatura del genoma umano. Intessere e connettere abilmente arte e scienza, ricamo e biologia molecolare con all'interno la rappresentazione grafica di alcuni geni del sangue. II ricamo come medium di 'riparazione'. Si assiste così alla messa in opera di un dispositivo sistematico come 
lavoro o come 'gioco' compiuto sulle differenti etnie unite in una unica rappresentazione che lo compongono in una struttura universale che si svela attraverso lo spazio analogico della tela [6]. II ricamo e il tessuto, il filo e l'ordito tessono un racconto universale, tessono la recinzione di un'area in eterno conflitto in cui la mappatura del genoma umano costituisce il filo conduttore del racconto di uno spazio artisticamente sottoposto ad un lògos che lo esprime. II principio insediativo dei popoli si trasforma cosi in principio compositivo della tela come proiezione dell'ordine cosmico del luogo mediterraneo e dei popoli insediati. La tela diventa il luogo dove si sedimentano tracce sovrapposte e trasparenti come caratteri connotativi e denotativi di popolazioni come esito del loro coesistere e sedimentare in una precisa regione fisica e rappresentativa. L'immagine del territorio mediterraneo attraversato dal ricamo del genoma suscita un senso di continuità, di aderenza al luogo, di movimento, una sorta di contenitore universale all'interno del quale trovano posto materialmente e concettualmente i popoli le cose e i fenomeni in uno spazio che consente di esistere la cui natura è fisica, biologica ed estetica contemporaneamente [7].

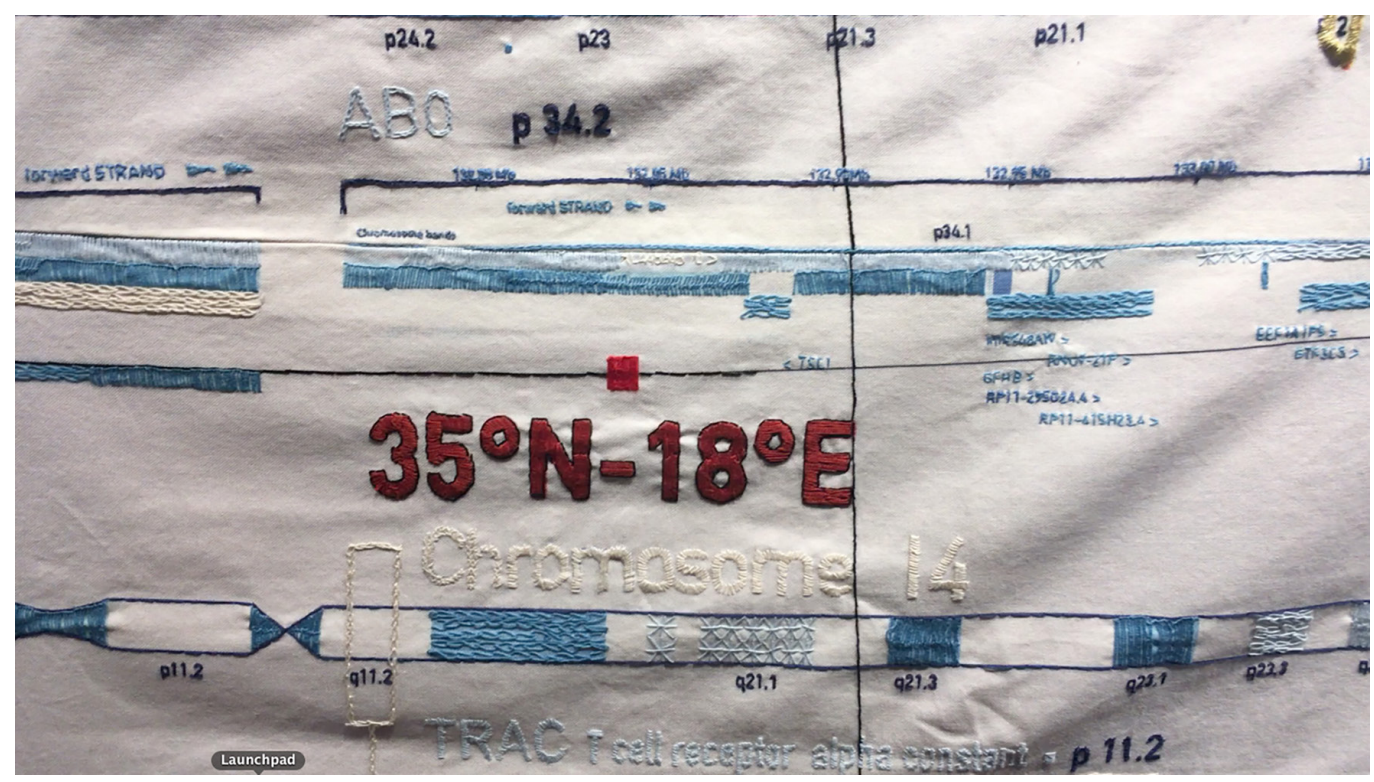

Un disegno che racconta una storia di solidarietà, che racconta la conformazione con cui la comunità dei popoli mediterranei crea la sua relazione con la natura e con gli altri individui per matrici di luogo e di tempo. La tela rappresenta così il valore mitico del principio insediativo mediterraneo che affonda nella sostanza più profonda dei rapporti terra/mare, orografia/geografia. La tela rappresenta trame e tessuti di luoghi storicamente determinati e costruiti. La tela sedimenta tracce sovrapposte e trasparenti. La tela induce ad un'ampia dialettica tra contenitore e contenuto tra intero, parte e sistema in un tentativo di unificazione fisica del luogo mediterraneo che attraverso la metafora del ricamo si è trasformato da principio insediativo in principio compositivo. La tela è attraversata dai geni del sangue, una serie di dodici geni che hanno un ruolo fondamentale nella funzione del sangue. Si crea così una dualità universale tra la rappresentazione del luogo e un tracciato riconoscibile che si fondono in un linguaggio comune, ordito da un filo d'oro senza il quale la memoria si smarrirebbe. Una ben precisa simmetria tra figura e caratteri genetici in un rapporto ciclico in cui il principio attivo creatore (il mare) e il materiale sul quale questo agisce (il genoma) riconducono alla rappresentazione che li contiene e li presuppone entrambi. I due fattori mare e genoma fungono da paradigmi conoscitivi, capaci di sintetizzare in una singola immagine svariati aggregati di significato. In ultimo annodare e tessere sono una forma di scrittura [8] che mette in relazione un pensiero teorico con una realtà fisica e territoriale e inventa 
una sorta di 'topografia'. Sia l'uno che l'altro presuppongono un filo, simboli antichissimi associati alla rappresentazione della donna nella sua domesticità laboriosa [Ugo 1982]. II filo e il tessuto rappresentano così il luogo della sedimentazione del gene umano, il luogo dove gli elementi di questo racconto trovano una reale fisicità in cui la tela, il filo, il gene umano e il ricamo della donna concorrono alla formazione di un insieme unitario. Un nuovo insieme inscindibile pena la perdita di una amplificazione lineare la cui funzione e il cui obbiettivo non è solo un casuale e disordinato assemblaggio ma configura materialmente un nucleo genetico come principio originario, 'origine' genetica che concorre alla formazione di un nuovo insieme che al livello di complessità raggiunta non può essere più scisso.

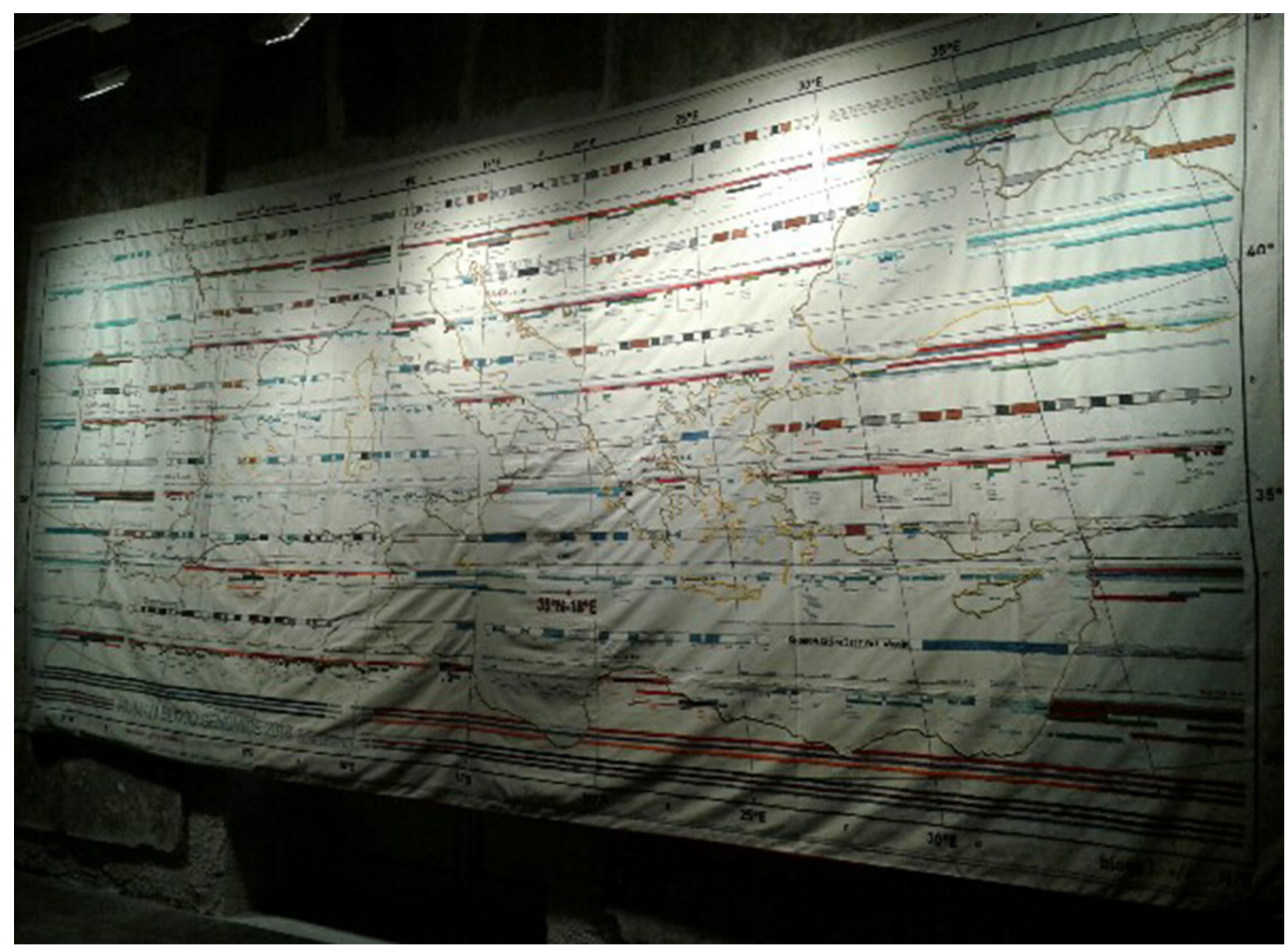

[I] Si veda in particolare il paragrafo 3.3: Teoria e progetto: forma, ragione, simbolo.

[2] Si veda in particolare: La descrizione Archeologica.

[3] L'opera presentata nella mostra al Museo Archeologico di Reggio Calabria è il risultato del lavoro di ricamo di alcune donne di etnie e appartenenze religiose diverse, quali palestinesi, israeliane, beduine e druse, che hanno iniziato a ricamare un arazzo chiamato II filo dell'Alleanza. Un arazzo che rappresenta il Mediterraneo. Sessanta donne di cinque etnie e religioni della Terra Santa, Israele e Palestina, tessono insieme associando al genoma umano, il sangue dell'uomo ricavandone un disegno che rappresenta il Mediterraneo. Un viaggio visionario e commosso di voci e racconti di donne. É un viaggio compiuto su un'opera d'arte, come un tappeto volante. E una geografia esterna (il mare Mediterraneo) e interna (il genoma) delle nostre vite.

[4] Si racconta una storia di solidarietà un'opera concreta e di destino comune in cui la terra e il mare sono separati da un filo d'oro che si fonde con la mappatura genetica del sangue di tutti gli uomini. "Attraverso la metafora del ricamo si possono ricucire gli strappi che ci sono nei Territori". II ricamo dunque non viene inteso solamente nelle sue intrinseche qualità immaginative e poietiche ma acquisisce il carattere di messaggio di riconciliazione e pacificazione. Il filo dell'alleanza è un'azione fortemente partecipata che discioglie le maglie di confini imposti e che vuole condurre ad una riflessione, sensibile e pertinente, sui principi di uguaglianza e di fraternità fra tutti i popoli, indipendentemente dalla loro religione e origine. Intessere e connettere abilmente arte e scienza, ricamo e biologia molecolare con all'interno la rappresentazione grafica di alcuni geni del sangue. II ricamo come medium di 'riparazione'. Ricamo e biologia molecolare.

[5] "A questo punto possiamo tentare di riassumere [...] che lo 'spazio' che la tela mette in gioco può riferirsi sia ad una struttura data come a-priori, neutra, astratta, universale, condizione preliminare di esistenza [... ] sia ad una struttura risultante da una produzione 'poietica' e che costituisce il campo delle relazioni: cioè è assai prossimo alla geometria topologica ed all'architettura come "cosa costruita' " [Ugo I991, p. 85]. Vedi anche: Ugo 1985b.

[6] II filo d'oro ricuce simbolicamente gli strappi e fa incontrare donne provenienti dai due Paesi, che desiderano conoscersi e lavorare insieme. Questo gruppo di lavoro si è infine incontrato a Gerusalemme, dove i sei lavori si sono assemblati in un'unica opera collettiva che rappresenta la mappa del Mediterraneo, una sorta di genoma umano che integra e definisce l'unicità e la somiglianza di ogni individuo, raffigurando i 12 geni che garantiscono la funzione del sangue. 
Fig. 5. Donne druse che ricamano la tela.

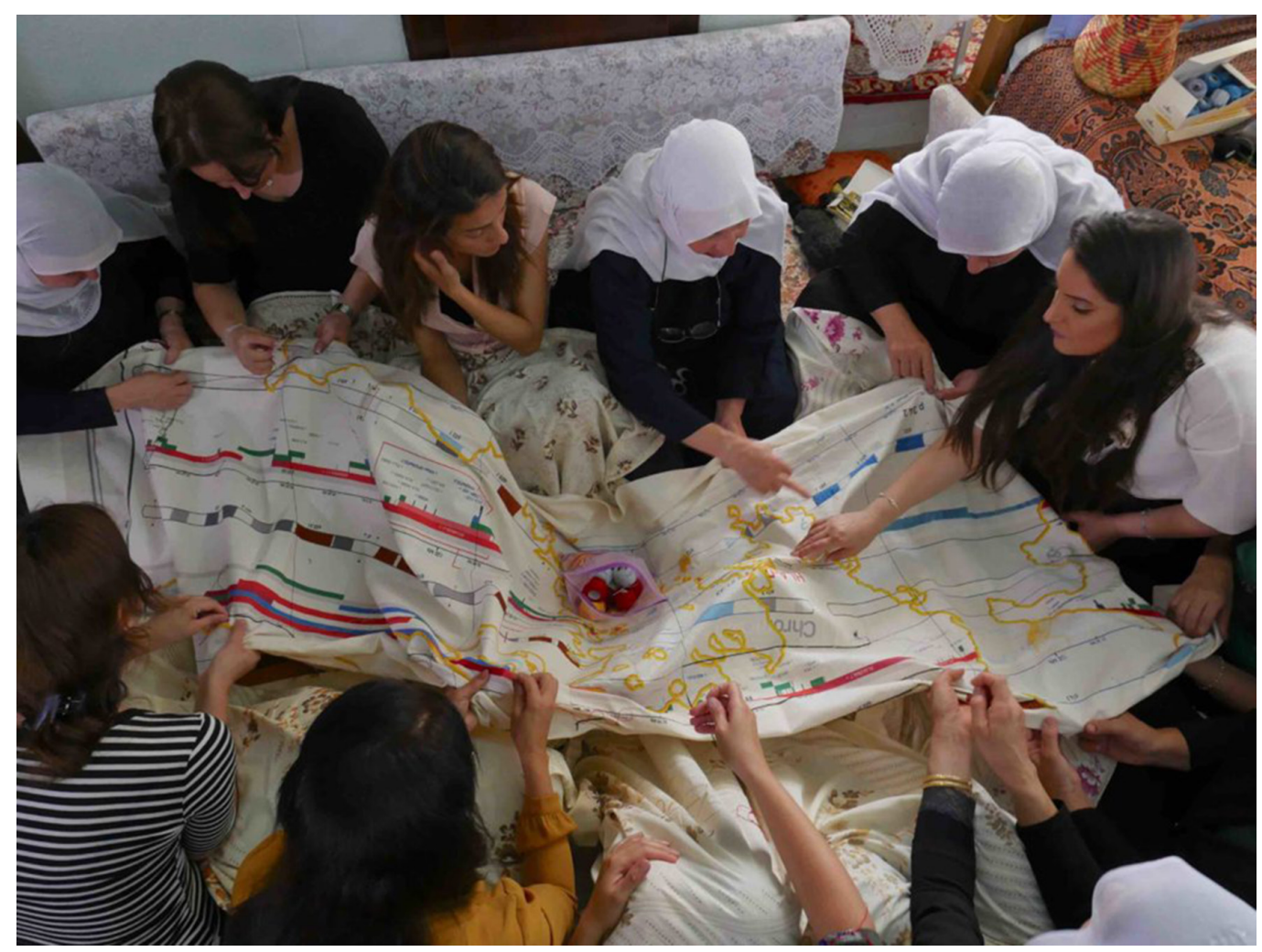

Fig. 6. Annodare e tessere.

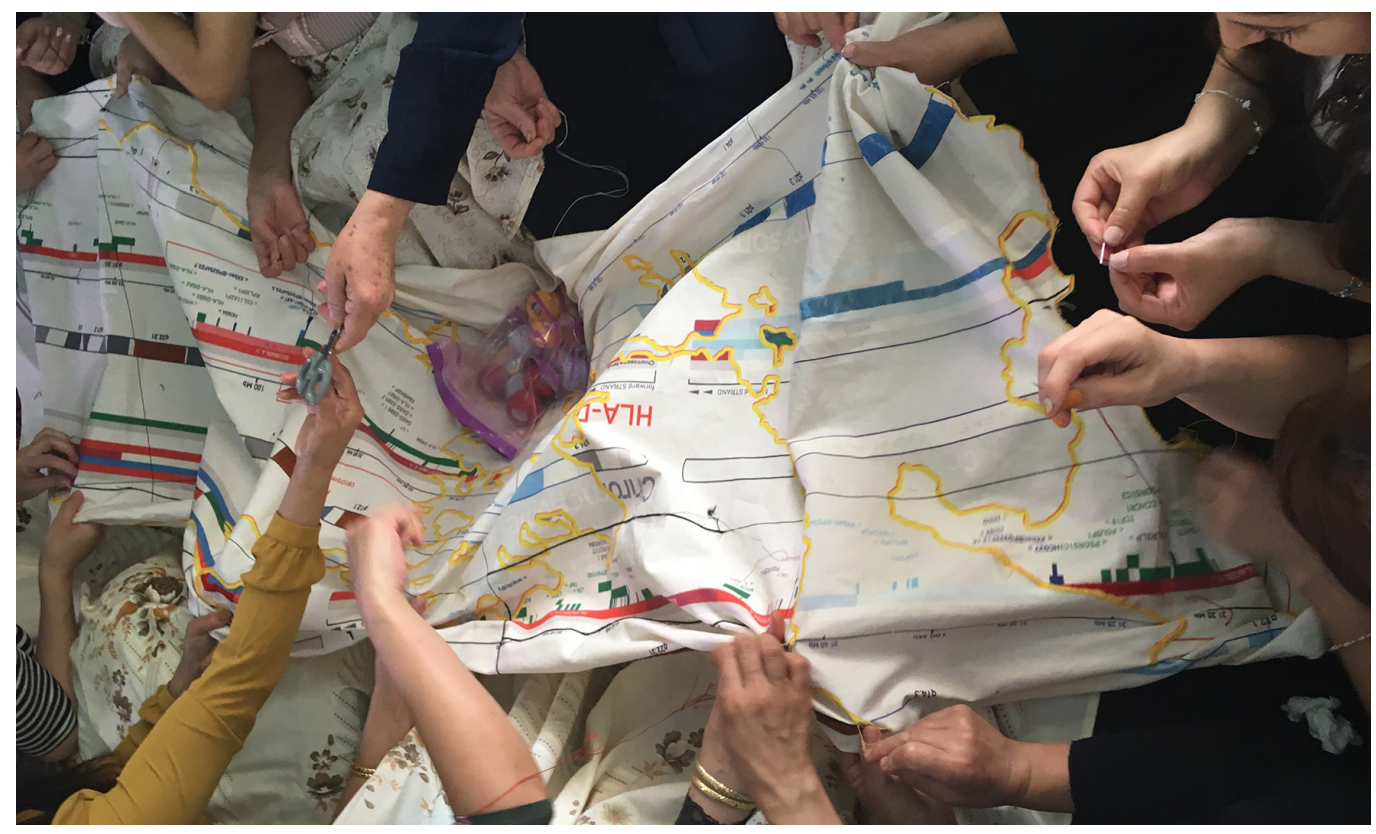


[7] Daniela Papadia, lei è artefice di un progetto artistico che si chiama Il Filo dell'Alleanza, che parte dalla mappatura del genoma. Attraverso l'intreccio dell'arte e della scienza il progetto vuole simbolicamente ricucire i fili interrotti del dialogo. In questo caso, quei fili servono a far ricamare l'arazzo a donne palestinesi e israeliane, che desiderano lavorare a un progetto comune nonostante le note divisioni. Questo per ricostruire visioni trascurate e riparare il groviglio, anche personale. L'arazzo riporta la mappa del mediterraneo, con un disegno di due metri e quaranta per cinque e sessanta. II disegno dell'arazzo è quello del genoma che integra e definisce l'unicità e la somiglianza di ogni persona. "Ho scelto il ricamo come mezzo espressivo perché è un'arte antichissima". La metafora dei fili e della tessitura è stata utilizzata in tutte le tradizioni dei vari popoli della terra. II filo è l'immagine della vita stessa e del destino al quale tutti siamo invisibilmente legati.

Mi piacerebbe che l'arazzo si trasformasse in un tappeto magico, come quello delle fiabe delle Mille e una notte, o come nella leggenda della regina di Saba che lo regala al Re Salomone, come pegno del suo amore. Si dice che un tappeto volante è tessuto su un telaio normale, ma che le sue tinture hanno poteri magici. Questi fili che corrono tra cielo e terra, possono far salire altri viaggiatori, che credono e sperano nel sogno dell'alleanza di un'unica 'razza', quella umana.

[8] Del progetto è stato realizzato un documentario prodotto da reporter e dall'Istituto Luce diretto da Francesco Miccichè. Italiano: <https://vimeo.com/35I564775>; inglese: <https://vimeo.com/292961766>.

\section{Riferimenti bibliografici}

A.A.V.V. (1982). Palermo: la memoria costruita. Palermo: Flaccovio.

A.A.V.V. (1984). Images et imaginaries d'architecture. Paris: Centre George Pompidou.

AA.W. ( 1992). Mediterranean landscape. Milano: Electa.

AA.W. (1993). Umm El Madayan. Una città araba nel Nord-Africa. Milano: Jaca Book.

AA.VV. ( 1996). Mediterraneo il mare delle complessità. Roma: CRES Edizioni lavoro.

Adonis (2002). La preghiera e la spada. Parma: Guanda.

Benjamin Walter (2007). Immagini di città. Torino: Einaudi.

Cassano Franco (1996). Il pensiero meridiano. Bari: Sagittari La Terza.

Cavalli-Sforza Luigi Luca (1996). Geni, popoli e lingue. Milano: Adelphi.

Cerizza Luca (2008). Alighiero e Boetti: Mappa. London: Afterall Publishing, London.

Chaliand Gérard, Rageau Jean-Pierre (1995). Atlas historique du monde mèditerranèen. Paris: Ed. Payot.

Derrida Jacques (1986). Architetture ove il desiderio può abitare. In Domus, n. 67I, aprile 1986, pp. 17-24.

Foucault Michel (197I). L'archeologia del sapere. Milano: Rizzoli, Milano.

Ginex Gaetano (2006). Urban Matrix. Incroci morfologici. In Massimo Giovannini, Daniele Colistra (a cura di). Spazi e culture del mediterraneo 2. Roma: Edizioni Kappa, pp. 347-363

Micara Ludovico (1985). Architettura e spazi dell'Islam. Roma: Carucci.

Matvejevic Pedrag (1987). Breviario mediterraneo. Milano: Hefti Edizioni.

Matvejevic Pedrag (199I). Mediterraneo, un nuovo breviario. Milano: Garzanti.

Micara Ludovico, Petruccioli Attilio, Vadini E. (2009). The Mediterranean Medina. Roma: International Seminar.

Morichini Ugo (1928). La Civiltà Mediterranea. Milano: Mondadori.

Nicolin Pierluigi (2002). Elementi di architettura. Milano: Skira.

Petruccioli Attilio (1985). Dar al Islam (architetture del territorio dei paesi islamici). Roma: Carucci.

Petruccioli Attilio (2008). Beyond the wall, Notes on multicultural mediterranean landscape. Bari: Unione Tipografica Editrice.

Ugo Vittorio (1976). Forma progetto architettura. Palermo: Flaccovio.

Ugo Vittorio (1982). Per una archeologia elementare dell'architettura. In Vittorio Ugo. Palermo: la memoria costruita. Palermo: Flaccovio, pp. $177-193$.

Ugo Vittorio (1985a). Fondamenti, principi archetipi dell'architettura. In Vittorio Ugo. L'architettura dell'organismo minimo come paradigma dell'architettura, la stanza, la piazza, la corte, il giardino. Palermo: Cogras. pp. 39-45.

Ugo Vittorio (1985b). L'architettura dell'organismo minimo come paradigma dell'architettura. Palermo: Cogras Palermo.

Autore

Gaetano Ginex, Università degli Studi Mediterranea di Reggio Calabria, ginex@unirc.it

Per citare questo capitolo: Ginex Gaetano (2020). Un 'telaio' teorico e le sue linee. II Filo dell'AlleanzalA theoretical 'chassis' and its lines. The Alliance's Thread. In Arena A., Arena M., Brandolino R.G., Colistra D., Ginex G., Mediati D., Nucifora S., Raffa P. (a cura di). Connettere. Un disegno per annodare e tessere. Atti del $42^{\circ}$ Convegno Internazionale dei Docenti delle Discipline della Rappresentazione/Connecting. Drawing for weaving relationships. Proceedings of the 42th International Conference of Representation Disciplines Teachers. Milano: FrancoAngeli, pp. 335 I-3364. 


\title{
A Theoretical 'Chassis' and Its Lines. The Alliance's Thread
}

\author{
Gaetano Ginex
}

\section{Abstract}

He puts on display in this writing, a longing for the reunion of distant places and souls, an openness to cultural intertwining in a quest for harmony between peoples in the sign of beauty and humanitas. There is talk of a collective work involving a group of women between Israel and Palestine, in a project that promotes integration and coexistence in the Mediterranean and the Middle East through the art of embroidery that becomes a tool to represent relationships, human contacts, exchanges of lives, intertwining words and cultures. It alludes to a the world's story by recognizing at the different cultures a full legitimacy and dignity as the cultures that have set their own lines of development and existence differently from us. An attempt to critically re-read the events of our civilization through a 'chassis' and an 'embroidery' which has as its theme the connection that exists in the complex relations between the Mediterranean' peoples, in which the design can be a final connective and place where all communities identify themselves in a simple and at the same time lasting act, through the metaphor of embroidery in a message that passes through the 'blood' of peoples that unites different lives in perpetual conflict.

Connect text, word and thought that interact through an artistic gesture.

Keywords

Mediterranean, gene, embroidery, thread, cards, classification.

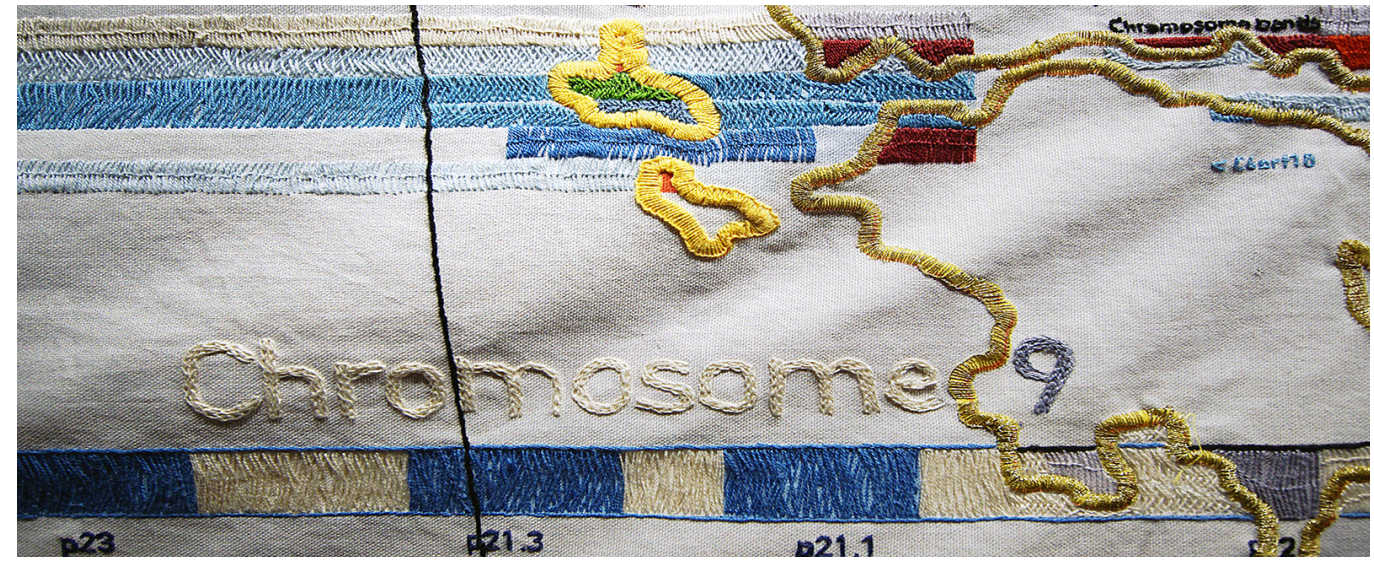


"Like the movement that constitutes the measure, time can only take place in a space. If the first is the place and the symbol of the imperfection is also the second; if the first is a set of discontinuous moments, the second will be a set of points. Just like time, space is the intermediary that assigns to man the precariousness of an earthly life that he crosses like a fragile bridge to rise up to heaven where the divine and absolute existence takes place.

This way of reducing time at instant and space to a point nullifies the same notion of randomness"

[Adonis 2002].

House is the physical place where the relationship is commonly established between human communities and the geographical territory, between the individual and the whole world, which in fact constitutes the matrix of all the architectural interventions that human groups have produced, and they produce over time: from the grave to the hearth, to the shelter, to the lodging, to the square, to the temple, to the city, to the whole territory. The house is an archetypal principle, is the primordial place of living and the fundamental topological field of architecture [Ugo 1976, pp. 53-6I] [I]. You can also have a theoretical and artistic need for an architectural metaphorization to make, that is to say, apply a technique other than the physical, material and semantic act of building a house and building an architectural metaphor in order to connect two non- homogeneous fields like that of the physical space, of the material construction and the artistic one in which gesture, text, word and thought interact through an artistic product. "The form's definitions and the symbol are in fact very concrete ideas, that is, it is a matter of carrying out, as Foucault says, an archeology, an analysis that cannot be separated from its use and its relevance" [Foucault I97I, pp. I55- 158] [2]. At this moment we allude to the concept and explanation of the origins of the world, at the classification and primitive ordering of things and phenomena. Recognizing full legitimacy and dignity to other cultures, giving them a new opportunity to critically reread the events of our civilization without too many easy certainties. A written text, a design process and a artistic act carries within it an ordering intention, so that the parts separated by life events can always reunite in unity and communicate universal messages full of archetypal principles. These are the terms that make up the 'chassis' within which we have sought a correct placement of these notes in harmony with the complex connections that exist in the fields of knowledge but also between multiple things in which design can be a ultimate connective for knowledge of cultural fields related to words, stories and myths. So, on the one hand the house's myth as a place where all communities identify themselves in a simple

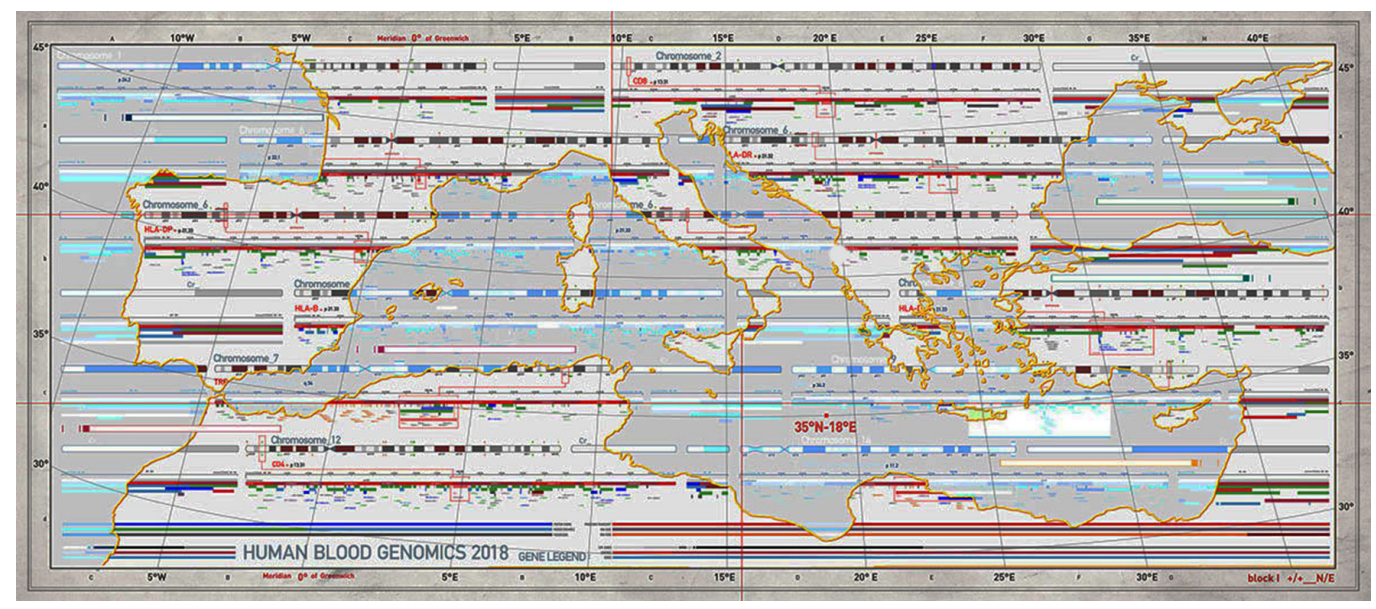


and lasting act as the habit and on the other the house's metaphorization as a symbol of a deeper identification of the communities all that selected 'the blood' as a vehicle of universal brotherhood [3]. The Mediterranean as a cultural mystery, an eternal place of dialogue and connections but a place of conflict and division that leads to a reflection that embodies an infinite dialogue between civilizations and cultures, tracing a long chain of meanings to reach of the brotherhood's dialogue of between peoples, assuming the appearance of a golden thread, a ribbon, a rope that winds through its borders in a hypothetical formal structure. To Narrate a space where a simple thread highlights a universal knowledge that knots and weaves a taxonomic seriality that evokes places, conflicts and wars forever. A single canvas divided into six parts that form an inseparable unity. An idea that offers the opportunity to

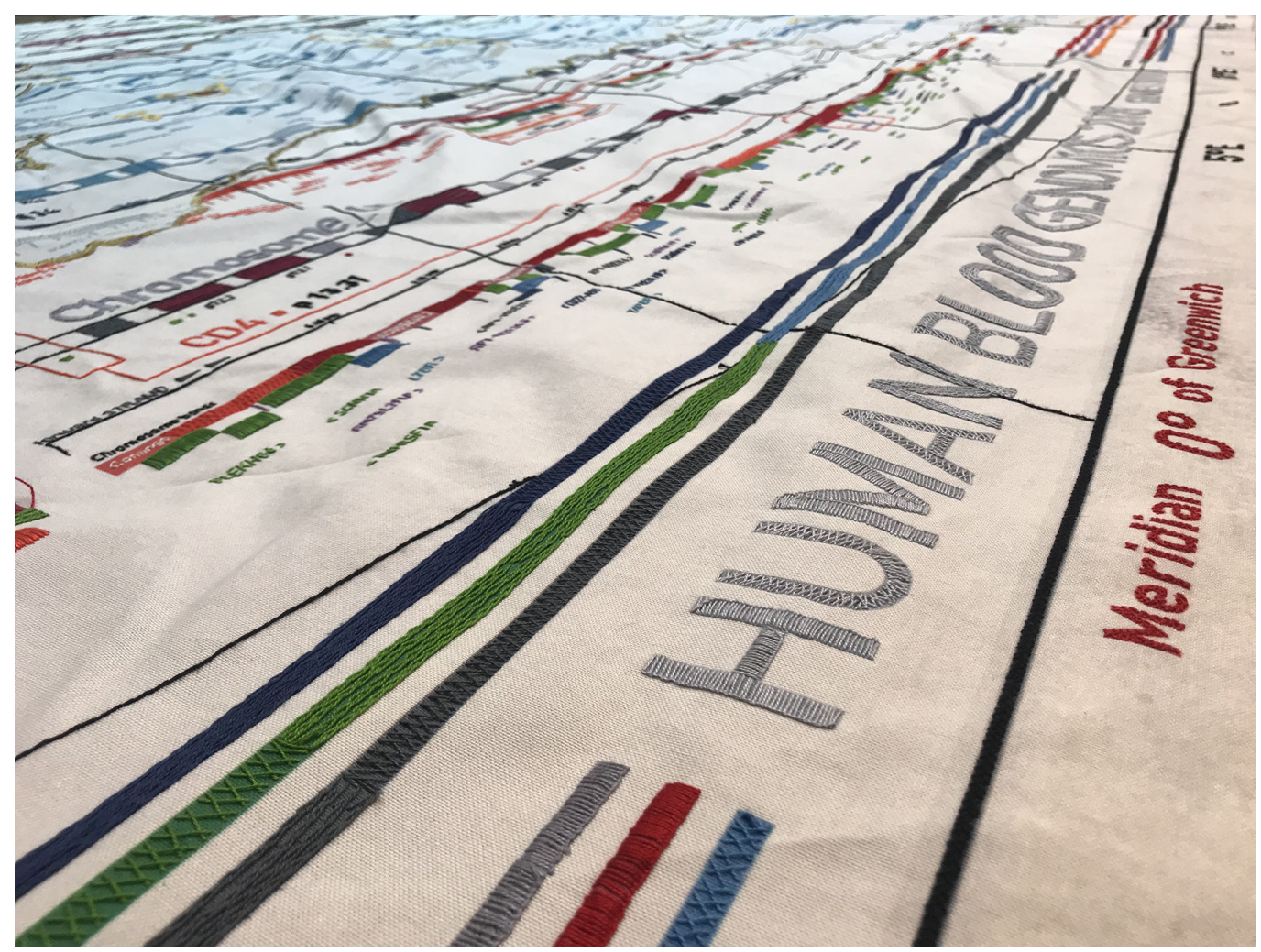

'connect' and an intention and a form appear outside the sensitive reality. A representation of elements without spatial congruence in a representation of genetic codes and of all ideas and forms that cannot be described inside the limits and rules of the Cartesian space. Space, time, place and history are put into action in an attempt to weave, through the embroidery, a work associated with the human genome, the blood of man as a drawing of the Mare Nostrum [4] in an attempt to establish the main contexts in which the message can be paradigmatically condensed. The context of 'ritual' and 'myth' as a field of perennial memory, the context of 'utopia' which definite space as absent memory and ultimately the context of heterotopia (out of time and out of place) as a poetic moment and critical memory field [5]. In this perspective, a complex system is obtained that includes three conceptual planes: the container space, the Mediterranean, the analogical space of the design represented by the canvas and the genetic field of reference included in the human genome's map. To weave and to connect art and science, embroidery and molecular biology with the graphic repre- 
sentation of some blood genes. Embroidery as a 'repair' medium. A systematic device as work or as a 'game' performed on the different ethnic groups united in a universal structure that is located in the analogic space of the canvas. (6) To weave, whit the embroidery and the fabric, the fence of an area in eternal conflict where the mapping of the human genome constitutes the guiding thread of the story of a space artistically subjected to a logos that expresses. The settlement principle of the peoples is thus transformed into the compositional principle of the canvas as a projection of the cosmic order of the Mediterranean place and of the settled peoples. The canvas becomes the place where overlapping and transparent traces settle as connotative and denotative characters of populations as a result of their coexistence and sedimentation in a precise physical and representative region. Whit the embroidery, the image of the Mediterranean territory express a sense of continuity, of adherence to the place, of movement, a sort of universal container within which peoples, things and phenomena are placed materially and conceptually in a space that exist whose nature is physical, biological and aesthetic at the same time [7]. A design that tells a story

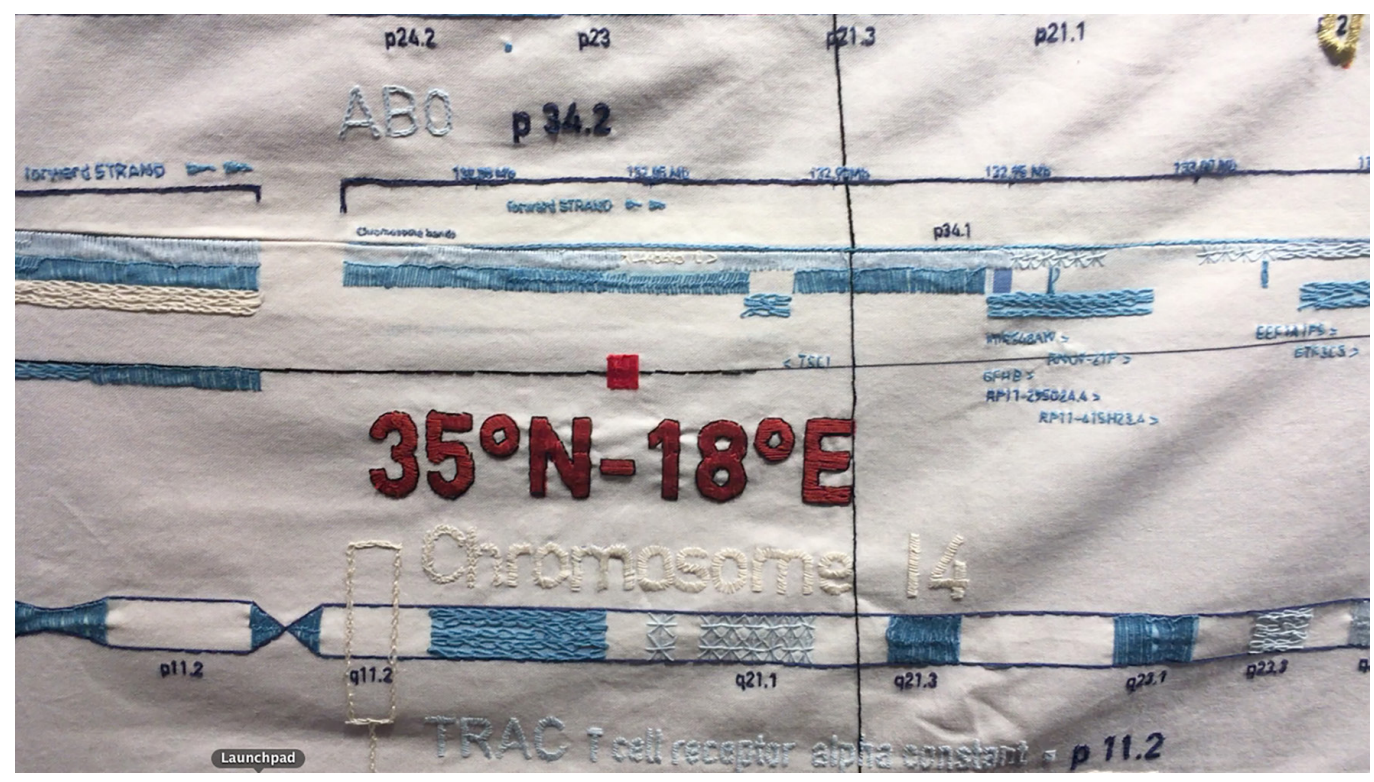

of solidarity with which the community of Mediterranean peoples creates its relationship with nature and with other individuals by means of place and time. The canvas represents the mythical value of the Mediterranean settlement principle which sinks into the deepest substance of the relationship between land/sea, orography/geography. The canvas, thus represents texture and fabrics of historically stored places. The canvas sediments overlapping and transparent traces. The canvas leads to a broad dialectic between container and content, in an attempt to physically unify the Mediterranean place which, through the metaphor of embroidery, has been transformed from a settlement principle into a compositional principle. The canvas is traversed by a series of twelve genes that play a fundamental role in blood function. This creates a universal duality between the representation of the place and a recognizable path, woven from a golden thread without which memory would be lost. A very precise symmetry between figure and genetic characteristics in a cyclical relationship in which the active principle creator (the sea) and the material on which it acts (the genome) lead back to the representation that contains them. The factors sea and genome act as cognitive paradigms, capable of synthesizing in a single image various meaning. To knot 
and to weave as writing [8] that connects theoretical thinking with a physical and territorial reality and invents a 'topography'. Both of them presuppose a thread, very ancient symbols associated with the representation of the woman in her laborious domesticity [Ugo 1982]. The thread and the fabric represent the place of sedimentation of the human gene, the place where the elements of this story find a real physicality in which the canvas, the thread, the human gene and the embroidery of the woman contribute to the formation of a unitary whole. A new inseparable whole, under penalty of losing a linear amplification whose function and goal is not only a random and disordered assembly but physically configures a genetic nucleus as the original principle, the genetic 'origin' that contributes to the formation of a new whole that can no longer be split.

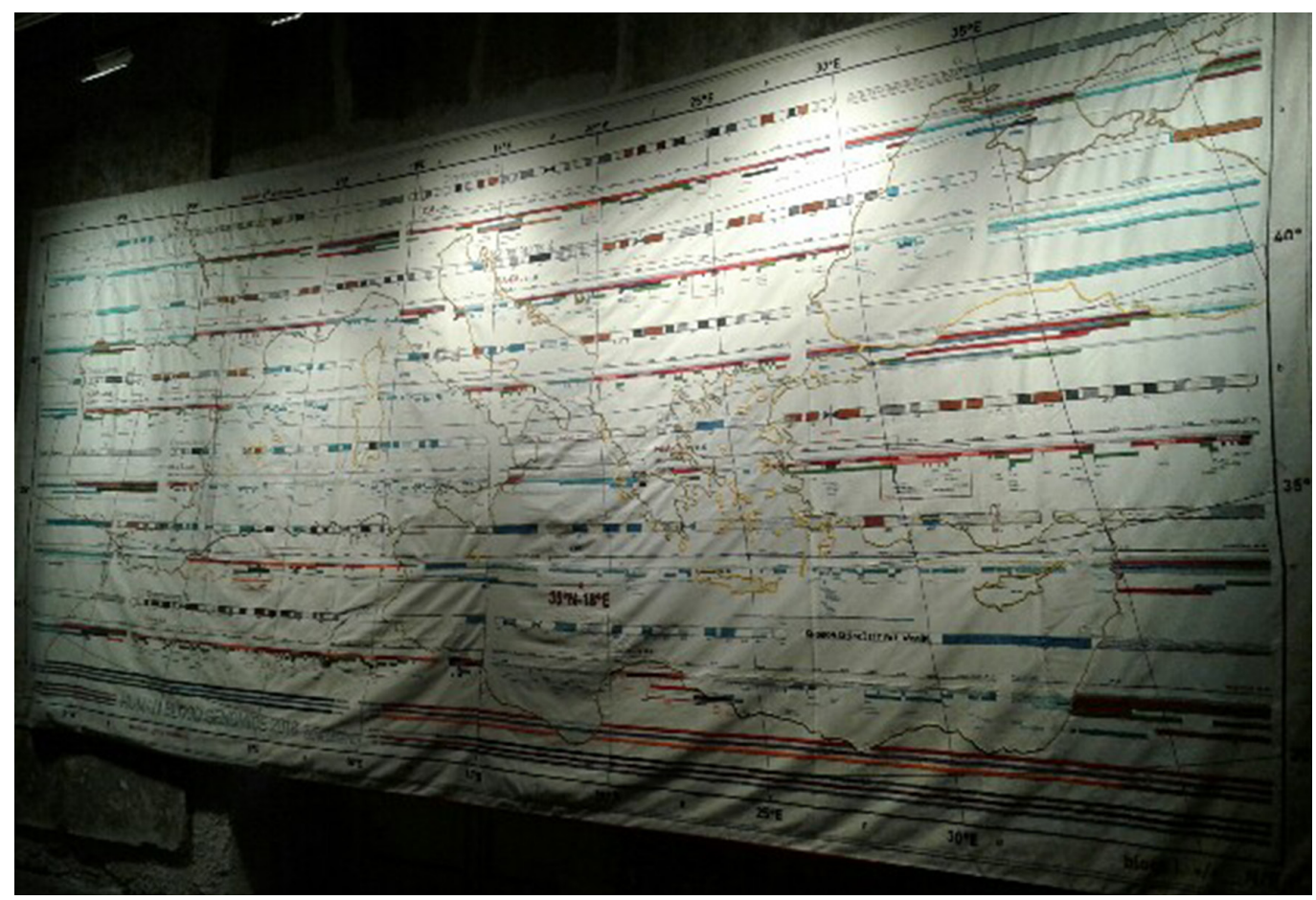

\section{Notes}

[I] In particular, see paragraph 3.3:Teoria e progetto: forma, ragione, simbolo.

[2] In particular, see: La descrizione Archeologica.

[3] The work presented in the exhibition at the Archaeological Museum of Reggio Calabria is the result of the embroidery work of women of different ethnicities and religious backgrounds, as Palestinians, Israelis, Bedouins and Druze, they have started to embroider a tapestry called The Alliance thread. A tapestry representing the Mediterranean. Sixty women of five ethnicities and religions from the Holy Land, Israel and Palestine, weave together by associating the human blood with the human genome, obtaining a design that represents the Mediterranean. A visionary and emotional journey of voices and stories of women. It is a journey made on a work of art, like a flying carpet. It is an external (the Mediterranean Sea) and internal (genome) geography of our lives.

[4] A story of solidarity is told, a work in which land and sea are separated by a golden thread that merges with the genetic mapping of the blood of all men. "Through the metaphor of embroidery, tears in the Territories can be mended". Embroidery is therefore not intended in its intrinsic imaginative and poetic qualities, but acquires the character of a message of reconciliation and pacification. The thread of the covenant is a participatory action which dissolves the meshes of the imposed boundaries and which aims to lead to a sensitive and pertinent reflection on the principles of equality and fraternity among all peoples, regardless of their religion and origin. Intertwining and connecting art and science, embroidery and molecular biology with the graphic representation of some blood genes inside. Embroidery as a means of 'repair'

[5] "We can try to summarize [...] that the "space" that the canvas brings into play can refer to a neutral, abstract, universal, preliminary condition of existence [...] and to a structure resulting from a "poietic" production which constitutes the field of relationships: that is, it is very close to topological geometry and architecture as a "constructed thing" [Ugo 199I]. See also: Ugo 1985b.

[6]The golden thread symbolically covers the tears and the women met by the two countries, know them and work together This working group is met in Jerusalem, where six works are assembled in connected collective work that describes the map of the Mediterranean, a sort of human genome that integrates and establishes the uniqueness and similarity of each individual, depicting the 12 genes which represent the function of the blood. 


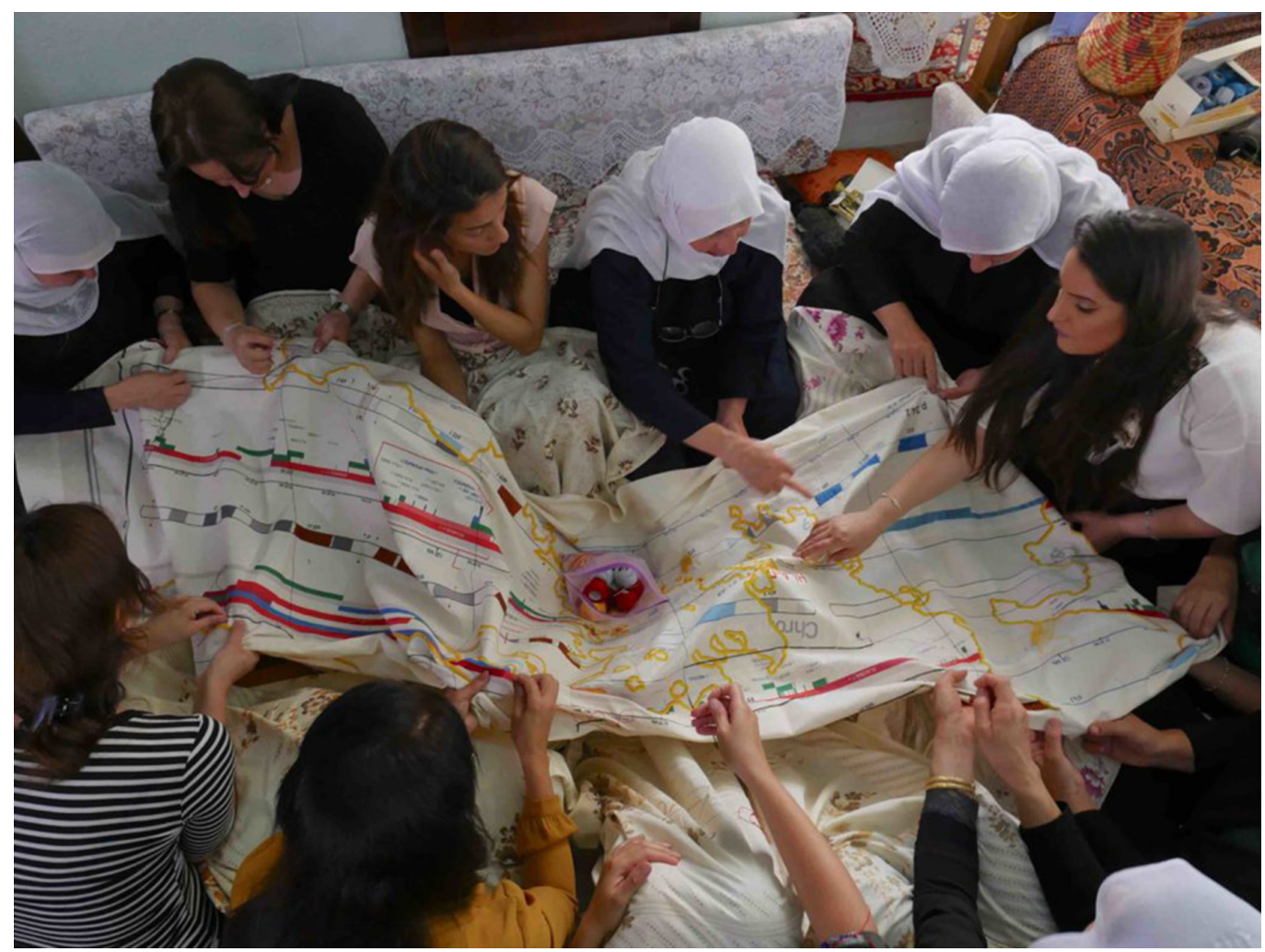

Fig. 6. Knot and weave.

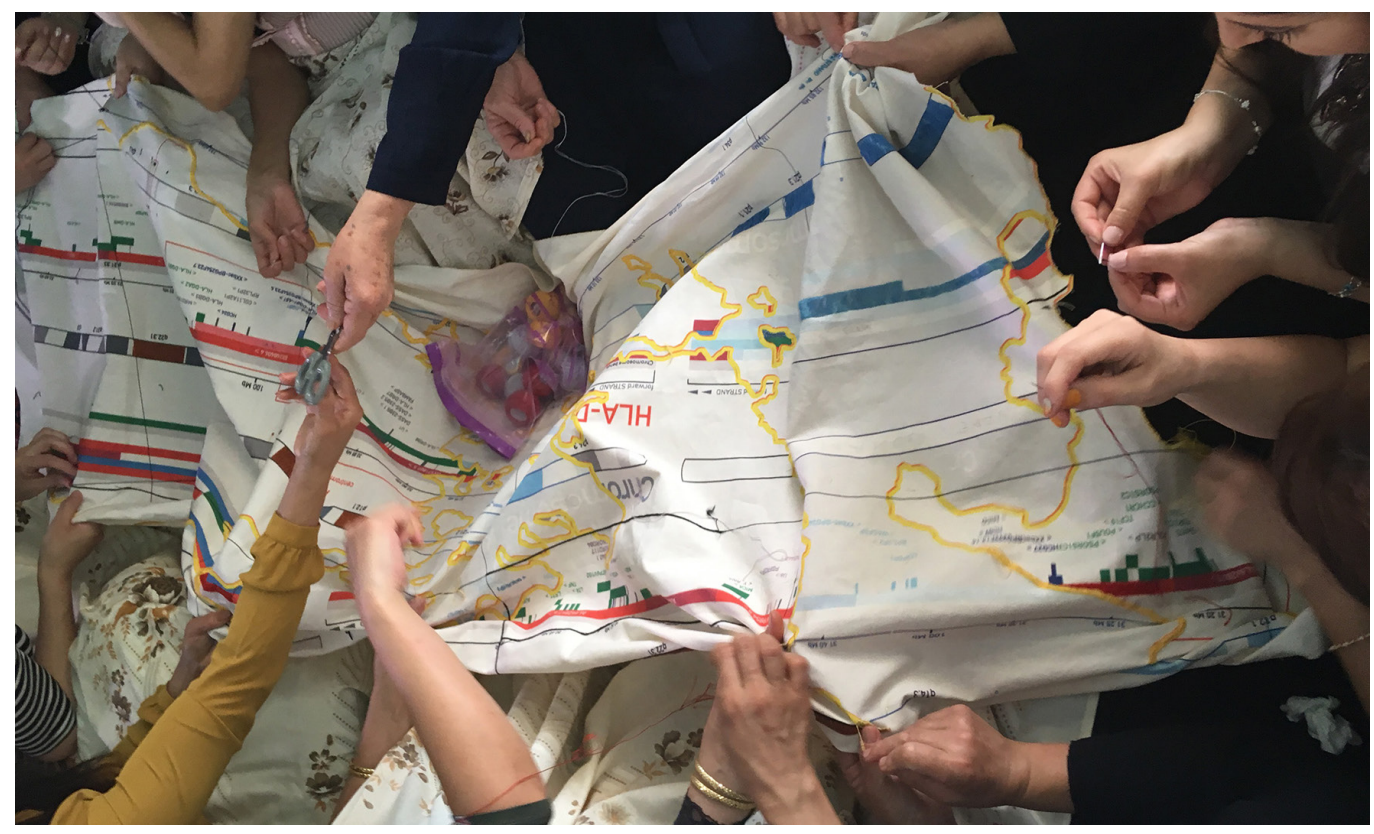


[7] Daniela Papadia, is the creator of an artistic project called I/ Filo dell'Alleanza, which is part of the genome mapping. Through the intertwining of art and science, the project symbolically seeks to mend the broken threads of dialogue. In this case, those threads served very far from the tapestry to Palestinian and Israeli women, who worked on a common project despite the known divisions. This is to reconstruct neglected visions and repair the tangle, even personal. The tapestry shows the map of the Mediterranean, with a drawing of two meters forty by five and sixty meters. The design of the tapestry is that of the genome which integrates and defines the uniqueness and similarity of each person. "I chose embroidery as an expressive medium because it is very ancient". The metaphor of threads and weaving has been used in all the traditions of the various peoples of the earth. The thread is the image of life itself and destiny to which we are all invisibly linked.

The pleasure that the tapestry turns into a magic carpet, like that of the fairy tales as the Thousand and One Nights, or as in the legend of the Queen of Sheba who gives King Solomon as a pledge of his love. A flying carpet is said to be woven on a normal loom, but its dyes have magical powers. These threads that run between heaven and earth can make other travelers rise, who believe and hope in the dream of the unique"race", the human race.

[8] A documentary produced by reporter and Istituto Luce directed by Francesco Miccichè. Italiam: <https://vimeo. com/35 | 564775>; english <https://vimeo.com/29296| 766 >.

\section{References}

A.A.V.V. (1 982). Palermo: la memoria costruita. Palermo: Flaccovio.

A.A.V.V. (1 984). Images et imaginaries d'architecture. Paris: Centre George Pompidou.

AA.V. ( 1992). Mediterranean landscape. Milano: Electa.

AA.VV. (1993). Umm El Madayan. Una città araba nel Nord-Africa. Milano: Jaca Book.

AA.W. ( 1996). Mediterraneo il mare delle complessità. Roma: CRES Edizioni lavoro.

Adonis (2002). La preghiera e la spada. Parma: Guanda.

Benjamin Walter (2007). Immagini di città.Torino: Einaudi.

Cassano Franco ( 1996). Il pensiero meridiano. Bari: Sagittari La Terza.

Cavalli-Sforza Luigi Luca (1996). Geni, popoli e lingue. Milano: Adelphi.

Cerizza Luca (2008). Alighiero e Boetti: Mappa. London: Afterall Publishing, London.

Chaliand Gérard, Rageau Jean-Pierre (1995). Atlas historique du monde mèditerranèen. Paris: Ed. Payot.

Derrida Jacques (1986). Architetture ove il desiderio può abitare. In Domus, n. 67I, aprile 1986, pp. 17-24.

Foucault Michel (197|). L'archeologia del sapere. Milano: Rizzoli, Milano.

Ginex Gaetano (2006). Urban Matrix. Incroci morfologici. In Massimo Giovannini, Daniele Colistra (a cura di). Spazi e culture del mediterraneo 2. Roma: Edizioni Kappa, pp. 347-363

Micara Ludovico (1985). Architettura e spazi dell'Islam. Roma: Carucci.

Matvejevic Pedrag (1987). Breviario mediterraneo. Milano: Hefti Edizioni.

Matvejevic Pedrag (199|). Mediterraneo, un nuovo breviario. Milano: Garzanti.

Micara Ludovico, Petruccioli Attilio, Vadini E. (2009). The Mediterranean Medina. Roma: International Seminar.

Morichini Ugo (1928). La Civiltà Mediterranea. Milano: Mondadori.

Nicolin Pierluigi (2002). Elementi di architettura. Milano: Skira.

Petruccioli Attilio (1985). Dar al Islam (architetture del territorio dei paesi islamici). Roma: Carucci.

Petruccioli Attilio (2008). Beyond the wall, Notes on multicultural mediterranean landscape. Bari: Unione Tipografica Editrice.

Ugo Vittorio (1976). Forma progetto architettura. Palermo: Flaccovio.

Ugo Vittorio (1982). Per una archeologia elementare dell'architettura. In Vittorio Ugo. Palermo: la memoria costruita. Palermo: Flaccovio, pp. $177-193$.

Ugo Vittorio (1985a). Fondamenti, principi archetipi dell'architettura. In Vittorio Ugo. L'architettura dell'organismo minimo come paradigma dell'architettura, la stanza, la piazza, la corte, il giardino. Palermo: Cogras. pp. 39-45.

Ugo Vittorio (1 985b). L'architettura dell'organismo minimo come paradigma dell'architettura. Palermo: Cogras Palermo.

Author

Gaetano Ginex, Università degli Studi Mediterranea di Reggio Calabria, ginex@unirc.it

To cite this chapter: Ginex Gaetano (2020). Un 'telaio' teorico e le sue linee. II Filo dell'Alleanza/A theoretical 'chassis' and its lines. The Alliance's Thread. In Arena A., Arena M., Brandolino R.G., Colistra D., Ginex G., Mediati D., Nucifora S., Raffa P. (a cura di). Connettere. Un disegno per annodare e tessere. Atti del $42^{\circ}$ Convegno Internazionale dei Docenti delle Discipline della Rappresentazione/Connecting. Drawing for weaving relationships. Proceedings of the 42th International Conference of Representation Disciplines Teachers. Milano: FrancoAngeli, pp. 335I-3364. 